\title{
Analisis Finansial Usaha Peternakan Babi (Studi Kasus Peternakan Babi UD Karang di Desa Jagapati, Kecamatan Abiansemal,Kabupaten Badung)
}

\author{
YOSSY ACHRIBSONE KUEAIN, I KETUT SUAMBA, \\ PUTU UDAYANI WIJAYANTI
}

Program Studi Agribisnis, Program Non Reguler, Fakultas Pertanian, Universitas Udayana. Jl. PB Sudirman 80232 Denpasar

Email: yossykueain@gmail.com

suamba_unud@yahoo.co.id

\author{
Abstract \\ Business Financial Analysis on Piggery \\ (A Case Study of Piggery of UD Karang at Jagapati Village, \\ Sub-District of Abiansemal, Badung).
}

Pigs is one commodity of livestock meat producer. Pigs have qualities and abilities that benefit namelyit hasfaster growth rate and also a higher number of piglets per birth. Pork demand has improved in the area of Bali that can provide business opportunities to UD Karang to develop a piggery by raising pigs to be fattening. Piggery business needs to do a financial analysis to determine the success of its business. The purpose of this study was to determine the feasibility of a piggery in terms of financial aspects and the obstacles being faced. This research was conducted on a piggery of UD. Karang located in the village of Jagapati, Abiansemal Subdistrict of Badung Regency. The analytical methods used were quantitative and qualitative methods. The study results and the conclusions showed that the piggery of UD Karang is financially feasible with NPV value of Rp 452, 693. 850, thenet value of $\mathrm{B} / \mathrm{C}$ of 1.3 and the IRR of $74.62 \%$. The obstacles faced by the piggery of UD Karang namely respiratory disease in swine livestock, price fluctuations, and environmental pollution. Suggestions given to UD Karang that it should work with the Department of Animal Husbandry and Animal Health, add good quality feed so as to meet the nutritional needs of the animals, and the pig manure should be fermentedto be utilized as biogas.

Keywords: pigs, financial analysis, obstacles

\section{Pendahuluan}

\subsection{Latar belakang}

Ternak babi merupakan salah satu komoditas ternak penghasil daging. Babi memiliki sifat-sifat dan kemampuan yang menguntungkan antara lainadalah memiliki laju pertumbuhan yang cukup cepat dan juga memiliki jumlah anak per kelahiran (litter size) yang tinggi (Bunter dan Bennett, 2004). Keuntungan lain dari beternak babi adalah makanan babi mudah didapat karena babi termasuk hewan 
omnivora (pemakan segala) serta kotoran babi sangat berguna sebagai pupuk. Jika dilihat dari kelebihan-kelebihannya tersebut maka babi memiliki potensi besar untuk dikembangkan sebagai penghasil daging.

Ternak babi di Indonesia telah cukup lama diketahui masyarakat, namun pengetahuan tentang beternak babi yang benar dan produktif belum banyak diterapkan, mengingat kurangnya informasi, akibatnya peternakan babi di Indonesia cenderung masih dilakukan secara tradisional bahkan masih banyak peternakan babi yang dikelola secara sangat sederhana dalam arti belum dikandangkan secara baik, belum diperhatikan pakan, pertumbuhan, perkembangbiakan, maupun kesehatannya (Nugroho dan Whendrato, 1990).

Ternak babi di daerah Bali masih mempunyai peranan yang sangat penting dalam menunjang ekonomi masyarakat khususnya di pedesaan. Sekitar $80 \%$ rumah tangga di pedesaan memelihara ternak babi yang jumlahnya antara tiga sampai lima ekor, meskipun bersifat sambilan, namun terbukti menjadi salah satu sumber pendapatan yang sangat diandalkan oleh keluarga. Peternak di Bali lebih banyak memilih babi ras jenis peranakan landrace untuk diternakan dibandingkan babi bali atau jenis babi lainnya. Alasannya, babi peranakan landrace pertumbuhannya lebih cepat dibandingkan babi jenis lain. Babi landracejuga memiliki kandungan lemak yang lebih sedikit dibandingkan dengan babi bali (Budiarsa, 2014).Permintaan daging babi yang terus meningkat maupun pangsa pasar yang sangat menjanjikan dapat memberikan peluang bisnis kepada UD Karang untuk mengembangkan bisnisnya dengan cara memelihara ternak babi untuk dijadikan penggemukan.

UD Karang merupakan usaha dagang ternak babi yang terdapat di Desa Jagapati, Kecamatan Abiansemal, Kabupaten Badungdengan memiliki jumlah populasi ternak babi mencapai ratusan ekor ternak babi dengan jenis landrace. UD Karang dalam kegiatan bisnisnya menjual ternak penggemukan ke Rumah Potong Hewan (RPH) dan juga kepada masyarakat adat setempat, maupun menerima pembeli atau konsumen yang datang langsung ke UD Karang. Penjualan dalam sebulan berkisar 20 sampai dengan 50 ekor ternak dengan harga perkilo gram sebesar Rp 25.000,00. Pakan ternak UD karang mengunakan dedak dan konsentrat, selain itu UD Karang bekerja sama dengan hoteluntuk mendapatkan limbah atau sisa-sisa makanan yang dijadikan pakan ternak babi.

Analisis finansial digunakan untuk menganalisis kriteria investasi bisnis. Kriteria investasi merupakan suatu ukuran yang menyeluruh sebagai dasar persetujuan atau penolakan tentang layak tidaknya suatu usaha ditinjau dari besar kecilnya pendapatan bersih yang dihasilkan, dengan menganalisis kelayakan finansial dapat diketahui layak atau tidaknya suatu usaha dijalankan.Kriteria investasi yang digunakan adalah Net Present Value (NPV), Net Benefit Cost (Net $\mathrm{B} / \mathrm{C}$ ), dan Internal ofReturn (IRR).Berdasarkan uraian diatas maka perlu dilakukan penelitian mengenai analisis kelayakan usaha yang ditinjau dari aspek finansial usaha peternakan babi di UD Karang, Desa Jagapati, Kecamatan Abiansemal, Kabupaten Badung. 


\subsection{Tujuan Penelitian}

Penelitian ini bertujuan untuk mengetahui kelayakan usaha peternakan babi UD Karang di Desa Jagapati ditinjau dari aspek finansial dan kendala yang dihadapi oleh usaha peternakan babi UD Karang di Desa Jagapati.

\section{Metode Penelitian}

\subsection{Lokasi dan Waktu Penelitian}

Penelitian ini dilakukan di peternakan babi UD Karang yang terdapat di Desa Jagapati, Kecamatan Abiansemal, Kabupaten Badung. Penelitian dimulai dari bulan Juni sampai dengan bulan Juli 2016.

\subsection{Penentuan Responden dan Informan Kunci}

Penelitian ini merupakan studi kasus di UD Karang, Desa Jagapati, Kecamatan Abiansemal, Kabupaten Badung. Responden dalam penelitian ini adalah semua karyawan maupun pemilik usaha di Peternakan babi U.D Karang, Desa Jagapati, Kecamatan Abiansemal, Kabupaten Badung yang berjumlah tujuh orang. Responden yang diambil dalam penelitian ini untuk rumusan masalah yang pertama menggunakan informan kunci yang terdiri dari pemilik usaha dan seorang karyawan bagian penggemukan dan keuangan sedangkan untuk rumusan masalah yang kedua responden yang diambil yaitu lima orang karyawan yang terdiri dari dua orang bagian penggemukan, dua orang bagian indukan dan anakan, serta satu orang bagian pengangkutan atau sopir.

\subsection{Metode Pengumpulan Data, Variabel Penelitian dan Analisis Data}

Metode pengumpulan data yang digunakan dalam penelitian ini adalah wawancara dan studi kepustakaan. Variabel dapat diartikan sebagai segala sesuatu yang akan menjadi objek pengamatan penelitian yang memiliki nilai yang bervariasi (Antara, 2006). Variabel dalam penelitian ini adalah analisis finansial, diukur secara kuantitatif dan kendala yang dihadapi peternakan babi UD Karang diukur secara deskriptif kualitatif. Analisis data yang digunakan dalam penelitian ini adalah analisis finansial dengan menggunakan kriteria investasi NPV, Net B/C, IRR serta analisis deskriptif kualitatif.

\section{Hasil dan Pembahasan}

\subsection{Karakteristik Responden}

Karakteristik responden antara lain : 1) Umur, merupakan salah satu faktor yang sangat penting dalam keefektifan bekerja di peternakan babi UD Karang sesuai dengan hasil wawancara, umur karyawan atau responden berkisar antara 21 sampai 35 tahun, sehingga dapat dikatakan karyawan atau responden bekerja pada umur yang produktif. Memiliki umur yang produktif diharapkan karyawan mampu bekerja dengan kemampuan yang tinggi sehingga dapat meningkatkan usaha peternakan babi 
UD Karang. 2) Faktor pendidikan sangat penting untuk menunjangnya operasional suatu perusahaan, karena jika diketahui tingginya tingkat pendidikan seseorang dapat mengetahui kemampuannya dalam bekerja maupun menyerap pengetahuan. Tingkat pendidikan karyawan yang bekerja di peternakan babi UD Karang sangat beragam yaitu jenjang SD berjumlah satu orang, SMP berjumlah tiga orang dan SMA berjumlah tiga orang. 3) Lahan, lahan yang digunakan dalam usaha peternakan babi UD Karang adalah lahan sewaan selama 20 tahun dengan harga Rp 10.000.000,00 pertahun seluas $1.500 \mathrm{~m}^{2}$, lahan ini digunakan untuk pembuatan kandang ternak babi dan penginapan untuk karyawan yang bekerja di UD Karang.

\subsection{Biaya dan Penerimaan UD Karang}

\subsubsection{Biaya}

Biaya merupakan semua pengorbanan yang perlu dilakukan untuk suatu proses produksi, yang dinyatakan dengan satuan uang menurut harga pasar yang berlaku, baik yang sudah terjadi maupun yang akan terjadi (Mahardhika, 2013). Biaya yang digunakan dalam usaha peternakan babi UD Karang yaitu biaya investasi dan biaya operasional.

\subsubsection{Biaya investasi}

Biaya investasi merupakan biaya atau pengeluaran proyek yang manfaatnya dapat dinikmati selama jangka waktu lebih dari satu tahun (Tuwo, 2011). Peternakan Babi UD Karang memiliki biaya investasi meliputi biaya kandang sebesar Rp 500.000.000,00, mesin pompa air sebesar Rp 4.000.000,00, ember air sebesar Rp 140.000,00, selang air sebesar Rp 910.000,00, dan drum sebesar Rp 400.000,00. Total biaya investasi selama enam tahun sebesar Rp 505.450.000,00.

\subsubsection{Biaya operasional}

Biaya operasional merupakan biaya yang digunakan untuk melaksanakan kegiatan-kegiatan dalam suatu proses produksi dan memiliki sifat habis pakai dalam kurun waktu relatif singkat (Anonim, 2013). Biaya operasional usaha peternakan babi UD Karang terdiri dari biaya tetap dan biaya variabel. Biaya tetap yaitu pajak bumi dan bangunan sebesar Rp 100.000 per tahun. biaya variabel meliputi pakan sebesar Rp 1.458.500.000,00, pengobatan sebesar Rp 80.000.000,00, listrik sebesar Rp 77.300.000,00, dan tenaga kerja sebesar Rp 669.600.000,00. Total biaya operasional selama enam tahun sebesar Rp 2.286.000.000,00.

\subsubsection{Pemasaran}

Pemasaran merupakan salah satu kegiatan yang dilakukan oleh pengusaha atau produsen dalam hal menjual produk yang dihasilkan guna untuk menghasilkan laba. Usaha peternakan babi UD Karang memasarkan atau menjual ternaknya dengan cara membawa langsung ke Rumah Potong Hewan (RPH), masyarakat adat 
setempat, maupun menerima konsumen atau pembeli yang langsung datang ke peternakan babi UD Karang.

Tabel 2.

Pemasaran Ternak Babi di Peternakan UD Karang dari Tahun 2010-2015

\begin{tabular}{ccc}
\hline Tahun & $\begin{array}{c}\text { Rata-Rata Bobot Badan } \\
\text { Ternak (per ekor/kg) }\end{array}$ & $\begin{array}{c}\text { Jumlah Ternak } \\
\text { (ekor) }\end{array}$ \\
\hline 2010 & 105 & 150 \\
2011 & 105 & 200 \\
2012 & 105 & 250 \\
2013 & 105 & 250 \\
2014 & 105 & 250 \\
2015 & 105 & 250 \\
\hline
\end{tabular}

Sumber: Peternakan Babi UD Karang

\subsubsection{Penerimaan}

Penerimaan merupakan arus kas yang masuk atau hasil penjualan ternak babi dari usaha peternakan babi UD Karang. Penerimaan pada usaha peternakan babi UD Karang berasal dari penjualan penggemukan ternak babi. Penerimaan usaha peternakan babi UD Karang dari tahun 2010 sampai 2015 adalah Rp 378.000.000,00, Rp 504.000.000,00, Rp 656.250.000,00, Rp 787.500.000,00, Rp 787.500.000,00, dan Rp 787.500.000,00. Total penerimaan selama enam tahun sebesar Rp 3.900.750.000,00. Selengkapnya dapat dilihat pada tabel 3 di bawah ini.

Tabel 3.

Penerimaan Usaha Peternakan Babi UD Karang dari Tahun 2010-2015

\begin{tabular}{cccccc}
\hline Tahun & $\begin{array}{c}\text { Jumlah } \\
\text { Penjualan } \\
\text { (ekor) }\end{array}$ & $\begin{array}{c}\text { Rata-Rata } \\
\text { Bobot Badan } \\
\text { kg/ekor }\end{array}$ & $\begin{array}{c}\text { Total } \\
\text { Penjualan } \\
(\mathrm{kg})\end{array}$ & $\begin{array}{c}\text { Harga } \\
\text { per kg } \\
(\mathrm{Rp})\end{array}$ & $\begin{array}{c}\text { Penerimaan } \\
(\mathrm{Rp})\end{array}$ \\
\hline 2010 & 150 & 105 & 15.750 & 24.000 & 378.000 .000 \\
2011 & 200 & 105 & 21.000 & 24.000 & 504.000 .000 \\
2012 & 250 & 105 & 25.000 & 25.000 & 656.250 .000 \\
2013 & 300 & 105 & 25.000 & 25.000 & 787.500 .000 \\
2014 & 300 & 105 & 31.500 & 25.000 & 787.500 .000 \\
2015 & 300 & 105 & 31.500 & 25.000 & 787.500 .000 \\
\hline Total & & & & & 3.900 .750 .000 \\
\hline
\end{tabular}

\subsection{Analisis Kelayakan Finansial}

Analisis finansial sangat diperlukan untuk menentukan kelayakan dalam usaha peternakan, usaha peternakan babi dikatakan layak atau tidaknya dapat dilihat dari besarnya perbandingan antara total penerimaan dan total biaya. Analisis finansial dalam usaha peternakan babi UD Karang menggunakan kriteria penilaian investasi. Kriteria investasi yang digunakan dalam penelitian ini untuk mencari kelayakan usaha peternakan babi UD Karang yaitu NPV, Net B/C, dan IRR. Tingkat 
suku bunga yang digunakan dalam penelitian ini yaitu tingkat suku bunga dari Bank BRI sebesar $18 \%$ per tahun. Analisis finansial usaha peternakan babi UD Karang dianalisis dari tahun 2010 sampai dengan tahun 2015 yaitu enam tahun.

\subsubsection{Net Present Value (NPV)}

Net Present Value merupakan selisih antara nilai sekarang arus manfaat dikurangi dengan nilai sekarang arus biaya yang telah didiskontokan setiap tahunnya (Gittinger, 1986). Berdasarkan perhitungan atau analisis mengenai NPV usaha peternakan babi UD Karang dengan menggunakan discount factor $18 \%$ sebesar Rp 452.693.850,00. Hasil perhitungan ini menunjukan bahwa usaha peternakan babi UD Karang layak diusahakan karena menghasilkan NPV bernilai positif. Artinya dari jumlah biaya yang dikeluarkan sebesar Rp 2.841.055.000,00 akan memperoleh penerimaan sebesar Rp 3.900.750.000,00 pada enam tahun yang akan datang, bila dilihat pada saat ini penerimaan tersebut bernilai sebesar Rp 452.693.850,00.

\subsubsection{Net Benefit Cost (Net B/C)}

Net Benefit Cost merupakan perbandingan antara penerimaan bersih dengan biaya secara keseluruhan yang telah didiskonto dengan discount factor (Gray, 1997). Hasil perhitungan Net B/C usaha peternakan babi UD Karang dengan discount factor $18 \%$ diperoleh nilai Net $\mathrm{B} / \mathrm{C}$ sebesar 1,3 . Hasil perhitungan ini menunjukan usaha peternakan babi UD Karang layak untuk diusahakan sebab Net B/C $(1,3)>1$. Artinya setiap pengeluaran sebesar Rp.1,00 maka akan memperoleh penerimaan sebesar Rp 1,3.

\subsubsection{Internal of Return (IRR)}

IRR menunjukan kemampuan proyek untuk menghasilkan bunga atau tingkat keuntungan dari sejumlah biaya yang akan dikorbankan (Widyantara, 2014). Pada dasarnya IRR menunjukkan tingkat bunga yang menghasilkan NPV sama dengan nol, dengan demikian untuk mencari IRR kita harus menaikkan discount factor (df) sehingga tercapai nilai NPV sama dengan nol.

Berdasarkan perhitungan dengan menggunakan discount factor $18 \%$ maka diperoleh IRR sebesar 74,62\%. Nilai IRR tersebut menunjukkan bahwa usaha peternakan babi UD Karang mampu untuk mengembalikan modal pinjaman bank sampai tingkat bunga maksimum sebesar 74,62\%, sehingga dapat diartikan bahwa usaha peternakan babi UD Karang layak diusahakan atau dilanjutkan sebab nilai IRR lebih besar dari discount factor. Hal tersebut sesuai pernyataan Umar (2005), bahwa usaha dikatakan layak untuk dijalankan jika nilai IRR > discount rate (i). 


\subsection{Kendala-Kendala yang dihadapi UD Karang}

Kendala yang dihadapi oleh usaha peternakan babi UD Karang di Desa Jagapati, Kecamatan Abiansemal, Kabupaten Badung dari hasil penelitian adalah sebagai berikut.

\subsubsection{Kendala teknis}

Kendala teknis usaha peternakan babi UD Karang yaitu masalah penyakit pernapasan pada ternak babi, dimana babi yang terserang penyakit ini tidak bisa diselamatkan. Akibat dari penyakit ini tingkat mortalitas tinggi sehingga perusahaan mengalami kerugian. Perusahaan berusaha melakukan pencegahan terhadap penyakit ini dengan cara vaksinasi terhadap ternak tetapi tidak begitu efektif untuk mengatasi penyakit ini, sehingga sampai saat ini penyakit pernapasan menjadi masalah atau kendala bagi usaha peternakan babi UD Karang.

\subsubsection{Kendala pasar}

Usaha peternakan babi UD Karang dalam kegiatan bisnisnya memasarkan atau menjual ternaknya di Rumah Potong Hewan (RPH). Kendala yang terjadi yaitu fluktuasi harga yang disebabkan oleh persaingan antara peternakan UD Karang dengan peternakan-peternakan babi lainnya yang skala usahanya besar, dimana ternak penggemukan dari UD Karang kualitasnya lebih rendah dari peternakan lainnya oleh karena itu tidak mampu bersaing sehingga harga jualnya rendah.

\subsubsection{Kendala sosial}

Kendala sosial yang dihadapi oleh usaha peternakan babi UD Karang yaitu adanya keluhan dari warga setempat mengenai pencemaran lingkungan yang disebabkan oleh bau kotoran ternak babi.

\section{Simpulan dan Saran}

\subsection{Simpulan}

Berdasarkan hasil analisis yang diuraikan di atas maka dapat disimpulkan halhal sebagai berikut.

1. Hasil analisis finansial usaha peternakan babi UD Karang dari tahun 2010-2015 dapat diketahui bahwa dengan menggunakan modal pinjaman bank ( tingkat suku bunga 18\%) maka diperoleh NPV bernilai positif, Net B/C lebih dari satu dan IRR lebih besar dari tingkat suku bunga yang berlaku, sehingga secara finansial usaha peternakan babi UD Karang layak diusahakan.

2. Kendala-kendala yang dihadapi usaha peternakan babi UD Karang adalah sebagai berikut.

a. Kendala teknis

Kendala teknis yaitu penyakit pernapasan pada ternak babi sehingga dapat menyebabkan tingkat mortalitasnya tinggi.

b. Kendala pasar 
Kendala pasar yaitu adanya persaingan di Rumah Potong Hewan sehingga terjadi fluktuasi harga

c. Kendala sosial

Kendala sosial yaitu adanya keluhan dari masyarakat mengenai pencemaran lingkungan yang disebabkan oleh bau kotoran ternak babi.

\subsection{Saran}

Berdasarkan hasil penelitian yang telah diuraikan maka dapat disarankan halhal sebagai berikut.

1. Peternakan babi UD Karang perlu melakukan kerja sama dengan Dinas Peternakan dan Kesehatan Hewan sehingga penyakit pernapasan pada ternak babi dapat ditangani dengan baik.

2. Peternakan babi UD Karang perlu menambahkan kualitas pakan yang baik sehingga dapat memenuhi kebutuhan gizi ternak dan mampu bersaing dengan peternakan lainnya.

3. Peternakan UD Karang diharapkan ke depannya kotoran ternak babi dapat difermentasikan untuk dijadikan biogas sehingga selain mengurangi pencemaran lingkungan biogas juga dapat bermanfaat sebagai bahan bakar.

\section{Ucapan Terima Kasih}

Penulis mengucapkan banyak terima kasih kepada semua pihak yang telah membantu dan memberikan motivasi dalam penyelesaian penelitian serta penulisan e-jurnal ini. Semoga penulisan ini dapat bermanfaat bagi yang membutuhkannya.

\section{Daftar Pustaka}

Anonim, 2013. Jenis-Jenis Biaya. Internet Artikel online. Http://biayabiaya.blogspot.co.id/. Diunduh 20 Juli 2016.

Antara, M. 2006. Metodelogi Penelitian Agribisnis. Bahan Ajar. Denpasar Universitas Udayana.

Budiarsa, K. 2014. Potensi Ternak Babi di Bali. Internet. Makalah online. https://repositori.unud.ac.id/upload/repositori/ID3_195812041985031002110 81408854makalah-babi-seminar-2014-edit---pdf.pdf. Diunduh 13 Mey 2016.

Bunter dan Bennet. 2004. Animal Science and Industry. Cetakan keempat. PrenticeHall, Inc. New Yersey.

Gittinger, J. P. 1986. Analisa Ekonomi Proyek-Proyek Pertanian. Penerjemah : Slamet.

Gray, dkk. 1997. Manajemen Proyek. Jayakarta: LPFE Universitas Indonesia.

Mahardhika, E. 2013. Pengertian Biaya. Internet. Artikel online. http://emahardhikaersa.co.id/2013/04/biaya/.html. Diunduh 27 Juli 2016

Nugroho, E dan Whendrato, I .1990. Beternak Babi. Eka Offset. Semarang.

Tuwo, M.A. 2011. Ilmu Usaha Tani: Teori dan Aplikasi Menuju Sukses. Kendari: Unhalu Press

Umar, Husein. 2001. Study Kelayakan Bisnis Edisi 3 Revisi. Jakarta : GramediaPustaka Utama. 
Widyantara, W. 2014. Perencanaan dan Evaluasi Proyek Pertanian. Bahan Ajar. Denpasar: Fakultas Pertanian Universitas Udayana. 